\title{
Survival Rate and Biochemical Parameters in Mugil cephalus (Linnaeus, 1758) Larvae Fed Garlic (Allium sativum L.) Extract
}

\author{
Mohammad Saeid Fereidouni' ${ }^{1}$, Paria Akbary ${ }^{2}$, Siyavash Soltanian ${ }^{1}$ \\ ${ }^{1}$ Animal Health Unit, School of Veterinary Medicine, Shiraz University, Shiraz, Iran \\ ${ }^{2}$ Department of Marine Sciences, Fisheries Group, Chabahar Maritime University, Chabahar, Iran \\ Email: ${ }^{*}$ paria.akbary@gmail.com
}

Received 24 December 2014; accepted 11 January 2015; published 19 January 2015

Copyright (C) 2015 by authors and Scientific Research Publishing Inc.

This work is licensed under the Creative Commons Attribution International License (CC BY). http://creativecommons.org/licenses/by/4.0/

c) (i) Open Access

\section{Abstract}

This study was carried out to investigate the effect of different concentrations of garlic (Allium sativum L.) extract in fish diet on survival rate, digestive enzymes and some biochemical parameters of Mugil cephalus larvae. Three hundred and sixty fish with mean weight $0.45 \mathrm{~g}$ were randomly divided into equal four groups; each one contained 3 replicates. Fish was fed with diets containing $0 \%$ (control), $0.5 \%, 1 \%$ and $3 \%$ concentrations of garlic extract (GE) in diet. 30 days after feeding, survival rate, different biochemical (larvae extract total protein, albumin, globulin, glucose, cholesterol and triglyceride) parameters and digestive enzyme activity (lipase, protease and amylase) were evaluated. There was a significant increase in survival rate of all groups fed with GE as compared to the control diet $(P<0.05)$. The administration of $A$. sativum in all levels significantly decreased $(P<0.05)$ the content of cholesterol, triglyceride and glucose in larvae extract. Also total protein, albumin and globulin levels had significantly increased in all groups fed GE $(P<0.05)$. The highest total protein $(2.13 \pm 0.12 \mathrm{~g} / \mathrm{dL})$, albumin $(0.37 \pm 0 \mathrm{~g} / \mathrm{dL})$, globulin $(1.76 \pm 0.12 \mathrm{~g} / \mathrm{dL})$, $\mathrm{amy}-$ lase (9.25 $\pm 0.14 \mathrm{U} / \mathrm{mg}$ protein), protease $(4.20 \pm 0.08 \mathrm{U} / \mathrm{mg}$ protein) and lipase $(2.62 \pm 0.14 \mathrm{U} / \mathrm{mg}$ protein) and the lowest serum triglyceride $(22.78 \pm 0.20 \mathrm{mg} / \mathrm{dL})$, glucose $(8.76 \pm 0.09 \mathrm{mg} / \mathrm{dL})$, cholesterol ( $3.69 \pm 0.07 \mathrm{mg} / \mathrm{dL})$ levels were observed in fish fed $3 \% \mathrm{GE}$ in diet. Garlic inclusion in fish diet at $3 \%$ concentration is therefore beneficial for use in aquaculture to improve the general health and digestive enzyme activity of $M$. cephalus larvae.

\section{Keywords}

Mugil cephalus, Garlic Extract, Biochemical Indices, Digestive Enzyme Activity

\footnotetext{
${ }^{*}$ Corresponding author.
}

How to cite this paper: Fereidouni, M.S., Akbary, P. and Soltanian, S. (2015) Survival Rate and Biochemical Parameters in Mugil cephalus (Linnaeus, 1758) Larvae Fed Garlic (Allium sativum L.) Extract. American Journal of Molecular Biology, 5, 7-15. http://dx.doi.org/10.4236/ajmb.2015.51002 


\section{Introduction}

Successful rearing of larval fish is the most critical stage in the production cycle for many species. Mugil cephalus has a promising market potential in Europe, East and South Asia [1]. It is also an important aquaculture species in Iran. The consumer demand stimulated the development of intensive aquaculture of this species in Asian countries. The problem in rearing larval fish is food supply [2]. Therefore a readily available, easily acceptable and highly digestible diet with high nutritional value should be used as larval fish starter diet [2] [3].

Plants are natural sources of safer and cheaper chemicals. Plant products have been reported to promote various activities like anti stress, growth promotion, appetite stimulation and immunostimulation in aquaculture practices [4] [5].

Garlic (Allium sativum) is one of known medicinal plants in aquaculture used as a flavoring agent, traditional medicine, and a functional food to enhance physical and mental health. Garlic was studied in different forms of extracts: aqueous, ethanol and dried powder [6] [7]. It contains a variety of organosulfur compounds such as allicin, ajoene, S-allylcysteine, diallyl disulfide, S-methylcysteine sulfoxide and S-allylcysteine [8].

Garlic inclusion in fish feeds has also been reported to increase growth performance in fish [9]-[11]. Khalil et al. [12] mentioned that garlic contained allicin which promoted the performance of the intestinal flora, thereby improving digestion, enhancing the utilization of energy, and leading to improved growth.

Metabolic activities of blood plasma of Clarias gariepinus [12] and Labeo ruhu [8] have been improved by the inclusion of garlic in fish feed. Dietary garlic decreases blood glucose by increasing the level of serum insulin [13] and the S-allylcysteine sulfoxide present in garlic is responsible for its hypoglycaemic activity [14] [15].

Garlic is useful for Mugil cephalus which is one of the commercially important culture fish in Iran due to their euryhaline, fast-growing, and disease resistant [1] [16].

Until now, no trial has been conducted to study the effect of dietary garlic extract on survival and some of serum biochemical parameters of grey mullet larvae. This study was therefore designed to investigate the effect of garlic on survival, larvae serum biochemical parameters (protein, glucose, albumin, globulin, cholesterol and triglyceride) and digestive enzyme activity of $M$. cephalus.

\section{Materials and Methods}

\subsection{Experimental Fish and Husbandry}

At Mid February, larvae of M. cephalus (average wet weight $0.45 \pm 0.11 \mathrm{~g}$ ) captured from the coastal water of Chabahar port, were transformed in the Researches Institute of Fisheries, Chabahar, Iran and stocked in a 500-L tank for quarantine and health check After quarantine, fish were acclimatized for one week in 400-L chlorinefree tap water and fed with commercial diet. Water exchange (50\%) was done daily and water quality was monitored throughout the experiment at weekly intervals. Temperature was $28.2^{\circ} \mathrm{C} \pm 0.5^{\circ} \mathrm{C}$, dissolved oxygen concentration $7.01 \pm 0.87 \mathrm{mg} / \mathrm{L}$, ammonia nitrogen concentration $0.11 \pm 0.04 \mathrm{mg} / \mathrm{L}$ and $\mathrm{pH} 7.8 \pm 0.4$. Fish were fed ad labium with commercially available pelleted feeds (Beyza Feed Mill Company, Iran) at the rate of $3 \%$ of body weight following assessment of biomass by bulk weighting every 7 days (thirty fish for each group). Growth was calculated based on the difference in the final body weight and initial body weight, and expressed as weight gain (\%). The daily ration was subdivided into two and fed at 9:00 hours and 16:00 hours.

\subsection{Preparation of Garlic Extract}

Two kg garlic (A. sativum) bulbs was obtained from the local market in Chabahar, Iran and oven dried at $60^{\circ} \mathrm{C}$, powdered by mortar and pestle and sieved Then garlic powder was left during $48 \mathrm{~h}$ in $99 \%$ ethanol $10 \mathrm{~L}(10 \%$ $\mathrm{w} / \mathrm{v})$ in room temperature $\left(24^{\circ} \mathrm{C} \pm 1.2^{\circ} \mathrm{C}\right)$ and the resulting extract was concentrated to $300 \mathrm{~mL}$ using rotary evaporator (IKA, Germany) giving the extract of $6.1 \mathrm{~g}$ of garlic powder $\mathrm{mL}^{-1}$. This extract was sprayed on the diet after dilution in $300 \mathrm{~mL}$ of distilled water [11].

\subsection{Preparation of Herbal Diets}

A commercial extruded pellet of $1.6 \mathrm{~mm}$ size (Beyza Feed Mill, Iran) was employed as the experiment diet. The analysed composition was as follows moisture $10 \%$, fibre $1.7 \%$, crude protein $50 \%$, crude fat $13.5 \%$ and crude ash $14.8 \%$. Four diets were prepared to contain $0 \%$ garlic extract (control diet), $0.5 \%$ (diet $2.0 \mathrm{~kg}+100 \mathrm{~mL}$ gar- 
lic extract $+300 \mathrm{~mL}$ distilled water), $1.0 \%$ (diet $2.0 \mathrm{~kg}+200 \mathrm{~mL}$ garlic extract $+300 \mathrm{~mL}$ distilled water) and 3.0\% (diet $2.0 \mathrm{~kg}+600 \mathrm{~mL}$ garlic extract $+300 \mathrm{~mL}$ distilled water) garlic extract. The mixture of garlic extracts and distilled water was sprayed on the experiment diets and dried in room temperature at $30^{\circ} \mathrm{C}$ for $48 \mathrm{~h}$ in order to volatilize remaining ethanol. All diets were stored at $-20^{\circ} \mathrm{C}$ until used [11].

\subsection{Experimental Design and Feeding Diet}

The study was conducted over a period of 30 days to evaluate the efficiency of garlic extract in promoting growth and carcass composition of grey mullet. Grey mullet larvae $(n=360)$ were divided into four equal groups. Three tanks (30 fish in each tank) were used in each group and randomly assigned to 12 plastic tanks each, $20 \mathrm{~L}$. Control group (1) was fed with basal diet and the remaining groups (2-4) were fed with $0.5 \%, 1 \%$ and $3 \%$ concentrations of garlic extract in diets respectively.

\subsection{Homogenate of Larvae and Digestive Tracts}

After 30 days of feeding, Larvae were starved for $24 \mathrm{~h}$ immediately after termination of the experiment. The number of surviving fish was recorded and used for calculating mortality. Nine fish (three fish per tank) from each group were selected at equivalent weight and anesthetized by clove oil $(5 \mathrm{mg} / \mathrm{L})$ to assay both digestive enzymes (protease, lipase and amylase) and some biochemical indices (total protein, cholesterol, glucose, albumin, triglyceride and globulin) serum biochemical parameters. For biochemical indices assay, larvae were washed two times with sterile phosphate buffer saline (PBS), pH 7.2, homogenized with 1 volume of PBS and centrifuged at $3000 \mathrm{~g}$ for $10 \mathrm{~min}$ at $4^{\circ} \mathrm{C}$. The supernatants were collected, centrifuged once at $3000 \mathrm{~g}$ for $5 \mathrm{~min}$ and stored at $-20^{\circ} \mathrm{C}$. Also for enzyme assay, the digestive tracts of larvae were carefully removed, thoroughly washed with PBS weighted and homogenized with chilled saline $(0.65 \%)$ and supernatant was extracted by centrifuged at $3000 \mathrm{~g}$ for $10 \mathrm{~min}$ at $4^{\circ} \mathrm{C}$.

\subsection{Assay of Some Biochemical Parameters}

The biochemical indices were determined with a Hitachi 917 (Hitachi, Tokyo, Japan) according to the commercially available diagnostic Experimental Protocols kits (Co. Pars Azmoon, Iran). These included total protein (g/dL larvae extract) (biuret method), albumin (g/dL larvae extract) (bromocresol green method), globulin (g/dL larvae extract) (subtracting albumin from total protein), triglyceride (mg/dL larva extract) (glycerol phosphate oxidase-paminophenazone method) and cholesterol (mg/dL larvae extract) (enzymatic endpoint method) levels. They were determined spectrophote metrically at $546 \mathrm{~nm}$ and $37^{\circ} \mathrm{C}$ [17] [18].

\subsection{Assay of Digestive Enzymes}

The influence of garlic extract on amylase, protease and lipase activities in the digestive tract was estimated by the method of Bernfeld [19] and Worthington [20]. Unit amylase activity was calculated as the weight (mg) of maltose liberated for a duration of $10 \mathrm{~min}$ at $30^{\circ} \mathrm{C}$. Unit protease activity was expressed as the amount of tyrosine liberated in 15 min under the assay conditions. Unit lipase activity was expressed as the amount of $0.025 \mathrm{~N}$ $\mathrm{NaOH}$ required to neutralize the fatty acids liberated during $18 \mathrm{~h}$ of incubation at $\mathrm{pH} 6.9$ and temperature $30^{\circ} \mathrm{C}$. The activities of digestive enzymes were calculated as enzyme unit per milligram protein $\left(\mathrm{U} \cdot \mathrm{mg}^{-1}\right.$ protein).

\subsection{Statistical Analysis}

Data are presented as means means \pm standard error (SE). All the biochemical parameters and digestive enzymes were analysed using one way analysis of variance (ANOVA) and significant differences among treatment means were compared using Duncan's multiple range test. Significance was tested at 5\% level and all statistical analysis was carried out using the SPSS Version 16.

\section{Results}

After 30 days of culture, survival rate in groups fed GE in diet was significantly higher $(P<0.05)$ than the control group. The highest survival rate of larvae 99\% was found in fish fed 3\% GE in diet while the lowest (87\%) was in the control group (as shown in Figure 1). There was no significant difference among fish fed different 
concentrations of GE in diet $(P>0.05)$.

The lowest glucose $(18.76 \pm 0.09 \mathrm{mg} / \mathrm{dL})$, triglyceride $(22.78 \pm 0.20 \mathrm{mg} / \mathrm{dL})$ and cholesterol $(3.69 \pm 0.07$ $\mathrm{mg} / \mathrm{dL}$ ) levels were observed in fish fed $3 \%$ GE in diet compared to the rest experimental groups and the control. Also there were significant different $(P<0.05)$ among all fish fed different concentrations of GE in diet in glucose, triglyceride and cholesterol levels (as shown in Figure 2).

After 30 days of feeding, the total protein and globulin and albumin levels were significantly higher $(P<0.05)$ in the experimental groups than the control group (as shown in Figure 3). The highest globulin (1.78 \pm 1.24 $\mathrm{g} / \mathrm{dL}$ ) level was observed in fish fed 3\% GE in diet compared to the rest experimental groups (Figure 3(c)). Albumin and total protein levels was slightly higher in fish fed $3 \% \mathrm{GE}$ in diet $(0.37 \pm 0$ and $2.13 \pm 0.12 \mathrm{~g} / \mathrm{dL}$ respectively) compared with fish fed $1 \% \mathrm{GE}$ in diet $(0.35 \pm 0$ and $1.86 \pm 0.01 \mathrm{~g} / \mathrm{dL}$ respectively) but showed no significant difference (Figure 3(a), Figure 3(b)).

Protease activity significantly $(P<0.05)$ increased in fish fed GE in diet (all concentrations).But for amylase and lipase activities, only at $1 \%$ and $3 \%$ GE in diet significantly $(P<0.05)$ varied. Highest amylase $(9.25 \pm 0.14$ $\mathrm{U} / \mathrm{mg}$ protein), lipase (2.62 $\pm 0.10 \mathrm{U} / \mathrm{mg}$ protein) and protease $(4.20 \pm 0.08 \mathrm{U} / \mathrm{mg}$ protein) activities were observed in at 3\% GE in diet. No difference was measured in activity of protease at $1 \%$ and $3 \%$ GE in diet (Table 1).

\section{Discussion}

Garlic is an important medicinal herb extensively cultivated in many countries and has played an important dietary function as well as medicinal role for centuries. In the present study, survival rate was significantly greater in all garlic-supplemented groups when compared with the control group at the end of the experiment (30 days after feeding). However, it was slightly higher in fish fed 3\% GE compared with fish fed $0.5 \%$ and $1 \%$ GE in diet, but showed no significant difference $(P>0.05)$. Although the use of garlic resulted in good survival rate, feeding the higher doses of garlic for extended periods gave better results. Using a combination of five herbs developed an Artemia-enriched herbal diet for Penaeus monodon, which significantly increased survival rate during stress conditions [4]. In agreement with the present results, Javadzadeh et al. [21] reported a significant increased survival rate (81.6\%) in which were fed enriched Artemia nauplii with $200 \mathrm{mg}$ garlic extract/L. In the present study, GE in diet enhanced total protein, globulin and albumin levels of $M$. cephalus larvae. Highest globulin level was observed in fish fed 3\% GE in diet compared to the rest experimental groups. Albumin and total protein levels was slightly higher in fish fed 3\% GE in diet compared with fish fed 1\% GE in diet, but showed no significant difference $(P>0.05)$. Which agrees with the results of increase in serum protein, albumin and globulin levels are thought to be associated with a stronger innate immune response and higher survival of fish [22]. Our results are comparable with those of Qompsell-which are extracts of several traditional chine's medicines have been found to significantly increase serum albumin, total protein and globulin in Cyprinus carpio

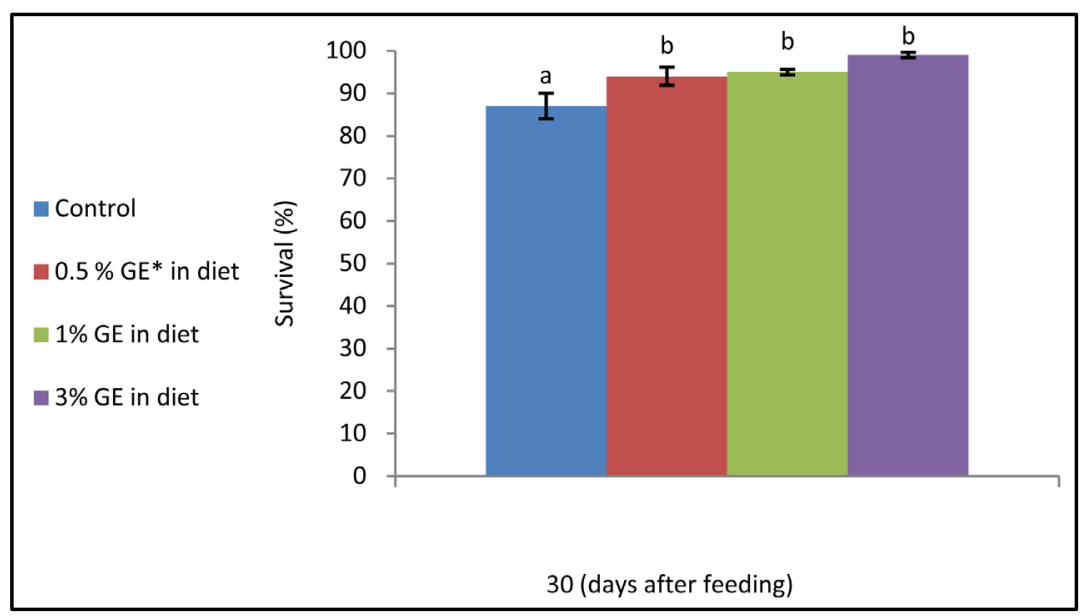

Figure 1. Survival rate in control and experimental groups. The values represent the mean \pm SE. Groups with the same superscript do not differ from each other $(P>$ 0.05). *Garlic extract. 


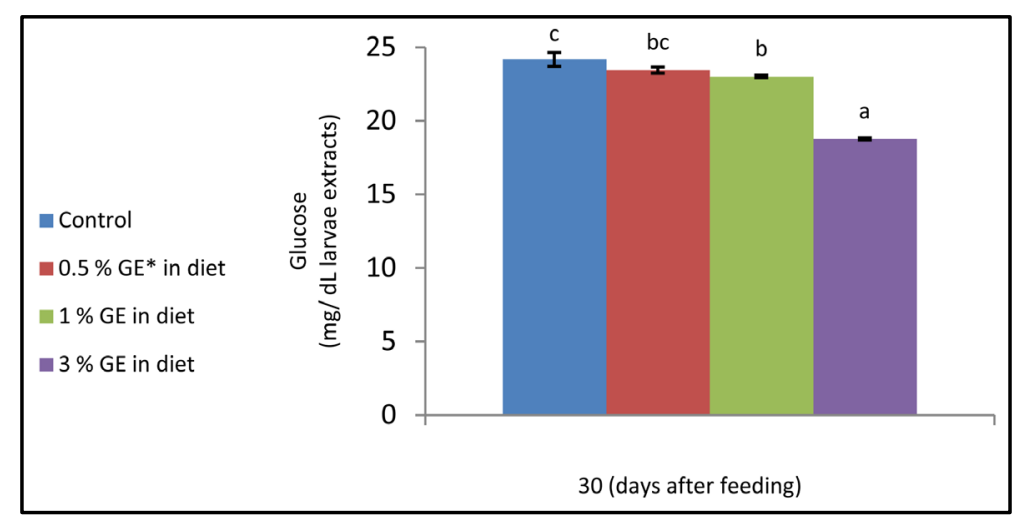

(a)

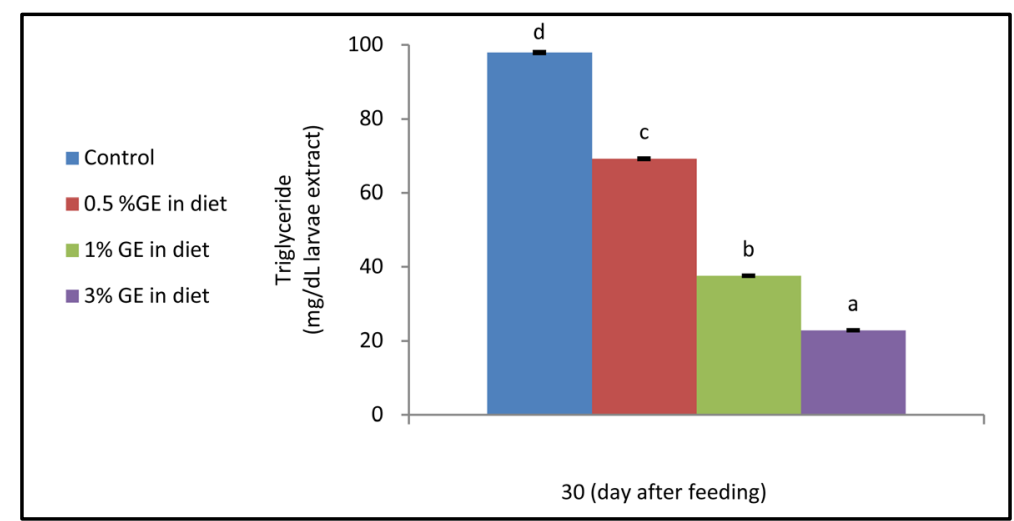

(b)

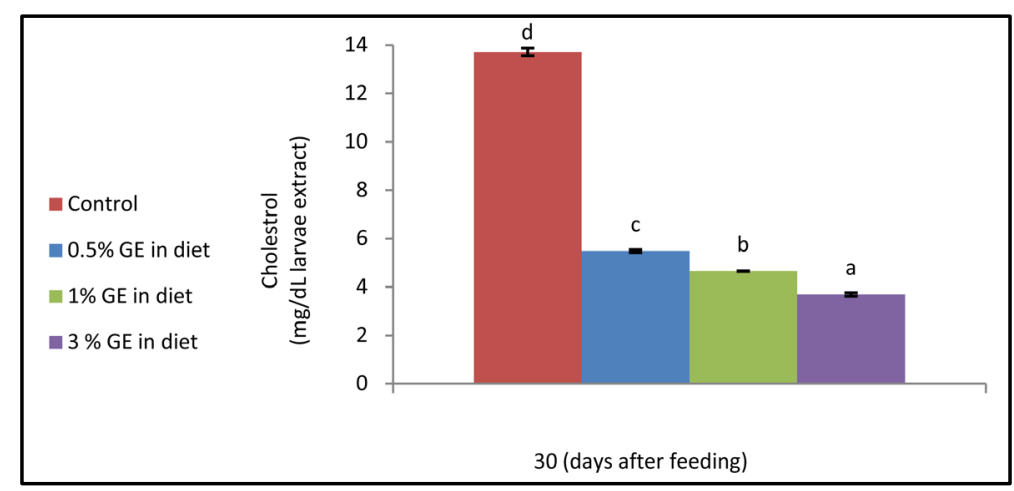

(c)

Figure 2. (a) Glucose, (b) triglyceride and (c) cholesterol levels in control and experimental groups. The values represent the mean $\pm S E(n=9)$. Groups with the same superscript do not differ from each other $(P>0.05)$. ${ }^{*}$ Garlic extract. Duncan's test.

by oral rout [23]. This finding is similar to earlier reports that total plasma protein in fish could vary from 2 - 8 $\mathrm{g} \cdot \mathrm{d}^{-1}$ [24]. Nwabueze [10] also reported increased levels of plasma protein in Clarias gariepinus and fed with different concentrations of garlic in diet. Sahu et al. [8] reported that the serum total protein, albumin and glucose levels in Labeo ruhu after 60 days feeding with A. sativum increased in comparison to the control diet. In the present study, plasma glucose concentration reduced significantly in fish fed on diets containing the highest level of Allium sativum (3\% in diet). These results agree with those of Lee et al. (2012) showed that hypoglycaemic effect for juvenile sterlet sturgeon (A. ruthensis) fed diet with $0.5 \%$ GE was accompanied with blood plasma glucose depletion after $1 \mathrm{~h}(50.8 \mathrm{mg} / \mathrm{dL})$ and $24 \mathrm{~h}(57.6 \mathrm{mg} / \mathrm{dL})$ of meal. Kumar and Reddy [25] and 


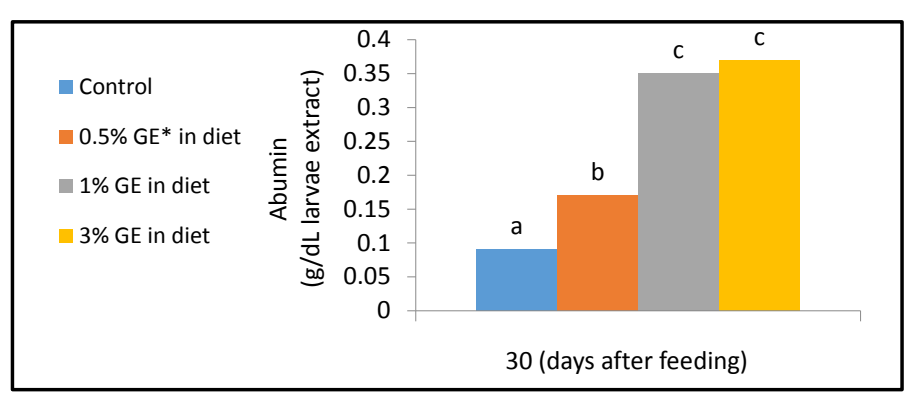

(a)

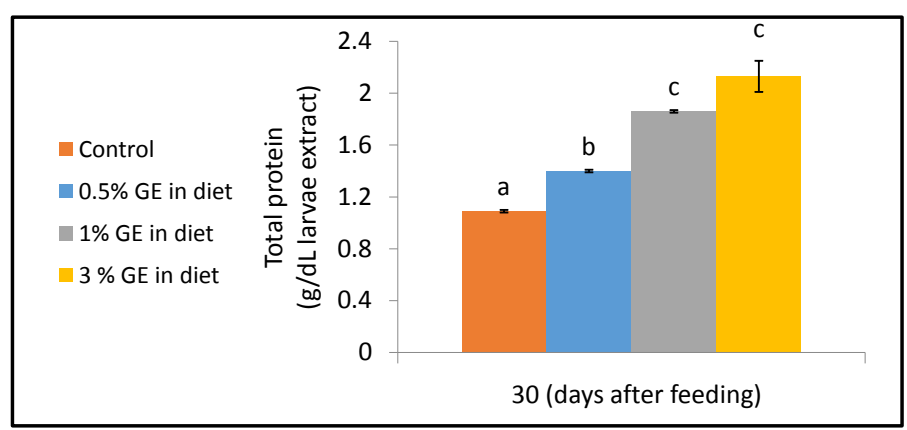

(b)

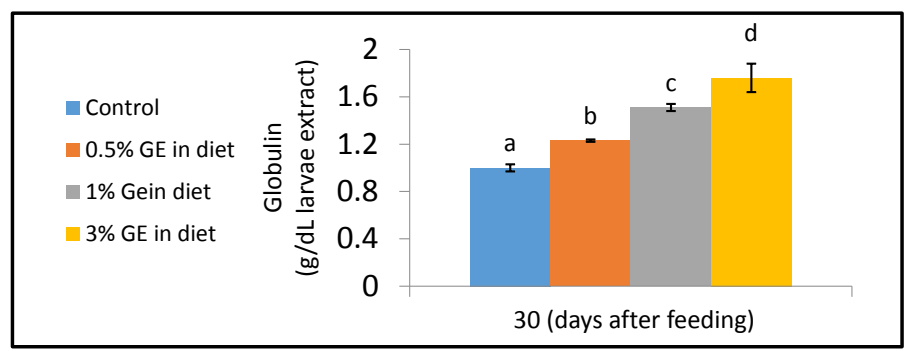

(c)

Figure 3. (a) Albumin, (b) total protein and (c) globulin levels in control and experimental groups. The values represent the mean \pm SE $(n=$ 9). Groups with the same superscript do not differ from each other $(P>$ 0.05). *Garlic extract. Duncan's test.

Table 1. Digestive enzymes levels in Mugil cephalus larvae fed diet with or without garlic extract at the end of experiment (30 days after feeding).

\begin{tabular}{cccc}
\hline Diet & Amylase (U/mg protein) & Lipase (U/mg protein) & Protease (U/mg protein) \\
\hline Control & $6.33 \pm 0.16^{\mathrm{a}}$ & $1.46 \pm 0.10^{\mathrm{a}}$ & $3.05 \pm 0.11^{\mathrm{a}}$ \\
$0.5 \% \mathrm{GE}^{*}$ & $6.50 \pm 0.13^{\mathrm{a}}$ & $1.79 \pm 0.07^{\mathrm{ab}}$ & $3.69 \pm 0.08^{\mathrm{b}}$ \\
$1 \% \mathrm{GE}$ & $8.30 \pm 0.09^{\mathrm{b}}$ & $2.15 \pm 0.12^{\mathrm{b}}$ & $3.96 \pm 0.07^{\mathrm{bc}}$ \\
$3 \% \mathrm{GE}$ & $9.25 \pm 0.14^{\mathrm{c}}$ & $2.62 \pm 0.10^{\mathrm{c}}$ & $4.20 \pm 0.08^{\mathrm{c}}$ \\
\hline
\end{tabular}

${ }^{*}$ Garlic extract. The values represent the mean \pm SE $(n=9)$. The values where are similar in columns are identified by the same superscript $(P>0.05)$. Duncan's test values.

Thomson and Alim [26] who found that feeding mice with $45 \mathrm{mg}$ garlic/kg body weight for 28 days induced significant decrease of serum glucose levels. Lower levels of plasma glucose in fish have also been reported in the assessment of physiological effects of Allium sativum [23] [27].

Dietary garlic decreases blood glucose by increasing the level of serum insulin [13]. According to VazquezPrieto et al. [14] and Ademiluyi et al. [15], the S-allyl cysteine sulfoxide present in garlic is responsible for its 
hypoglycaemic activity. In the groups fed GE in diet (different concentrations) was observed a significant decrease in glucose, cholesterol and triglyceride levels. The lowest triglyceride and cholesterol levels were observed in fish fed 3\% GE in diet compared to the rest experimental groups and the control $(P<0.05)$. These results are in agreement with the study by Adler and Holub [28], who verified that serum total lipid and total cholesterol decreased significantly in men treated with garlic and fish oil alone or combined. Also, Hussein et al. [22] found that the serum total lipid decreased significantly in albino rats after administration of garlic. Conversely, other study on C. carpio showed that Qompsel (extracts of several traditional Chinese medicines), enhanced the serum triglyceride and cholesterol levels slightly, but none were significantly different. The different composition and quantity of sulfur components of different garlic preparations used in various studies could account for the inconsistent findings. It highlights the need for standardization of different garlic preparations and to arrive at a valid conclusion. Other factors might include the subject recruitment, duration of study, dietary control, lifestyle and methods of lipid analyses [29].

This study indicated that garlic extract contained abundant proteins, but only a few lipids. The findings conform to those Lee et al. [13] who reported that garlic inhibits the synthesis of cholesterol and fatty acids in the liver; however, the exact mechanisms are not well understood. Therefore, further studies should be done to establish the relationship between the dose used, period of application.

Apart from enhancing the taste and flavor of food, spices have been widely believed to exert digestive stimulant action. Spices such as mint and garlic play a very important role in fat digestion and absorption [13]. The results of the present study indicate that A. sativum plays a positive role on activities of amylase, lipase and protease. Highest digestive enzyme activities in 3\% GE in diet fed larvae were shown, probably, because of the high concentration of compounds such as allicin, ajoene, S-allylcysteine, etc. [14]. Similar positive observations were reported by Venkatramalingam et al. [30]. A significantly $(P<0.05)$ improvement of digestive enzyme activity (amylase, protease and lipase) were observed that in post larvae of $P$. monodon fed with different percentage $(0 \%, 25 \%, 75 \%$ and $100 \%)$ of the herbal appetizer Zingiber officinalis enriched Artemia, after 30 days of culture [30], In another study, the effect of Livol (IHF-1000), as a herbal growth promoter, on the rohu, Labeo rohita, the Livol incorporated diet stimulated digestive enzyme activity and led to increased consumption [31]. Generally all spices shorten the feed transit time; this reduction was more prominent in the case of A. sativum. Also, the increases in enzyme production can result in improvements in digestibility and availability of nutrients from feedstuffs [32]. Reducing the amount of undigested material passing into the large intestine limits the amount of substrate available for proliferation of pathogenic bacteria. The enhanced proteolytic and lipolytic activities in the digestive tract of the GE in diet fed larvae could also be linked to better protein and lipid digestibilities [33].

\section{Conclusion}

Finally, the results of the present study indicate that A. sativum plays a positive role on activities of amylase, lipase and protease. Highest digestive enzyme activities in 3\% GE in diet fed larvae were shown, probably, because of the high concentration of compounds such as allicin, ajoene, and S-allylcysteine. Also, the enhanced proteolytic and lipolytic activities in the digestive tract of the GE in diet fed larvae could also be linked to better protein and lipid digestibilities.

\section{Acknowledgements}

The authors are thankful to the Director, Central Institute of Fisheries Researches, Chabahar, Iran, for providing necessary facilities during this study.

\section{References}

[1] Yelghi, S., Shirangi, S.A., Ghorbani, R. and Khoshbavar Rostami, H.A. (2012) Annual Cycle of Ovarian Development and Sex Hormones of Grey Mullet (Mugil cephalus) in Captivity. Iranian Journal of Fisheries Sciences, 11, $693-703$. http://www.jifro.ir

[2] Akbary, P., Hosseini, S.A. and Imanpoor, M.R. (2011) Enrichment of Artemia Nauplii with Essential Fatty Acids and Vitamin C: Effect on Rainbow Trout (Oncorhynchus mykiss) Larvae Performance. Iranian Journal of Fisheries Sciences, 10, 557-569. http://www.jifro.ir/ jifro/browse.php

[3] Girri, S.S., Sahoo, S.K., Shu, B.B., Sahu, A.H., Mohanty, S.N., Mohanty, P.K. and Ayyappan, S. (2002) Larval Survival and Growth in Wallago attu (Bloch and Schneider): Effects of Light Photoperiod and Feeding Regims. Aquacul- 
ture, 213, 157-161.

[4] Citarasu, T., Sekar, R.R., Babu, M.M. and Marian, M.P. (2002) Developing Artemia Enriched Herbal Diet for Producing Quality Larvae in Penaeus monodon. Asian Fisheries Science, 15, 21-32. http://www.asianfisheriessociety.org/publication/abstract.php?id=633

[5] Sivaram, V., Babu, M.M., Citarasu, T., Immanuel, G., Murugadass, S. and Marian, M.P. (2004) Growth and Immune Response of Juvenile Greasy Groupers (Epinephelus tauvina) Fed with Herbal Antibacterial Active Principle Supplemented Diets against Vibrio harveyi Infections. Aquaculture, 237, 9-20. http://dx.doi.org/10.1016/j.aquaculture.2004.03.014

[6] Shin, S.H. and Kim, M.K. (2004) Effect of Dired Powders or Ethanol Extracts of Garlic Flesh and Peel on Lipid Metabolism and Antithrombogenic Capacity in 16-Month-Old Rats. Hanguk Yongyang Hakhoechi, 37, 515-524.

[7] Ebrahim Dorche, I., Tangestani, R., Alizadeh Dvghyklayy, E. and Zare, P. (2013) Effect of Different Levels of Garlic Essential Oil on Growth, Feed and Carcass Composition of Beluga (Huso huso) Rearing Young. Journal of Marine Science and Technology, 11, 1-12. http://jmst.sinaweb.net/

[8] Sahu, S., Das, B.K., Mishra, B.K., Pradhan, J. and Sarangi, N. (2007) Effect of Allium sativum on the Immunity and Survival of Labeo rohita Infected with Aeromonas hydrophila. Journal of Applied Ichthyology, 23, 80-86. http://dx.doi.org/10.1111/j.1439-0426.2006.00785.X

[9] Shalaby, A.M., Khattab, Y.M. and Abdel Rahman, A.M. (2006) Effects of Garlic (Allium sativum) and Chloramphenicol on Growth Performance, Physiological Parameters and Survival of Nile Tilapia (Oreochromis niloticus). Journal of Venomous Animals and Toxins Including Tropical Diseases, 12, 172-201. http://dx.doi.org/10.1590/S1678-91992006000200003

[10] Nwabueze, A.A. (2012) The Effect of Garlic (Allium sativum) on Growth and Haematological Parameters of Clarias gariepinus (Burchell, 1822). Sustainable Agriculture Research, 1, 222-228. http://dx.doi.org/10.5539/sar.v1n2p222

[11] Lee, D.H., Ra, C.S., Song, Y.H., Sung, K.I. and Kim, J.D. (2012) Effects of Dietary Garlic Extract on Growth, Feed Utilization and Whole Body Composition of Juvenile Sterlet Sturgeon (Acipenser ruthenus). Asian-Australasian Journal of Animal Sciences, 25, 577-583. http://dx.doi.org/10.5713/ajas.2012.12012

[12] Khalil, R.H., Nadia, B.M. and Soliman, M.K. (2001) Effects of Biogen and Levamisol HCl on the Immune Response of Cultured Oreochromis niloticus to Aeromonas hydrophila Vaccine. Beni-Suef Veterinary Medicine Journal Egypt, 11, 381-392.

[13] Lee, D.H., Lim, S.R., Ra, C.S. and Kim, J.D. (2012) Effects of Dietary Garlic Extracts on Whole Body Amino Acid and Fatty Acid Composition, Muscle Free Amino Acid Profiles and Blood Plasma Changes in Juvenile Sterlet Sturgeon, Acipenser ruthenus. Asian-Australasian Journal of Animal Sciences, 25, 1419-1429. http://dx.doi.org/10.5713/ajas.2012.12184

[14] Vazquez-Prieto, M.A., Lanzi, C.R., Lembo, C., Galmarini, C.R. and Miatello, R.M. (2011) Garlic and Onion Attenuates Vascular Inflammation and Oxidative Stress in Fructose-Fed Rats. Journal of Nutrition and Metabolism, 2011, Article ID: 475216. http://dx.doi.org/10.1155/2011/475216

[15] Ademiluyi, A.O., Oboh, G., Owoloye, T.R. and Agbebi, O.J. (2013) Modulatory Effects of Dietary Inclusion of Garlic (Allium sativum) on Gentamycin-Induced Hepatotoxicity and Oxidative Stress in Rats. Asian Pacific Journal of Tropical Biomedicine, 3, 470-475. http://dx.doi.org/10.1016/S2221-1691(13)60098-2

[16] Yousefian, M., Ghanei, M., Pourgolam, R. and Rostami, H.K. (2009) Gonad Development and Hormonal Induction in Artificial Propagation of Grey Mullet, Mugil cephalus L. Research Journal of Fisheries and Hydrobiology, 4, 35-40. http://www.aensiweb.com/old/jasa/rjfh/2009/35-40.pdf

[17] Fawcette, J.K. and Scott, J.E. (1960) Practical Clinical Biochemistry. 4th Edition, Arnold Harold Varley, 119-122.

[18] Henry, R.J. (1968) Clincal Chemistry, Principles and Techniques. Harper and Row, New York, 664-666.

[19] Bernfeld, P. (1951) Amylase a and b in Methods in Enzymes. Academic Press, New York, 144-147.

[20] Worthington, C.C. (1991) Worthington Enzyme Manual Related Biochemical. 3rd Edition, Freehold, 212-215.

[21] Javadzadeh, M., Salarzadeh, A.R., Yahyavi, M., Hafezieh, M. and Darvishpour, H. (2012) Effect of Garlic Extract on Growth and Survival Rate in Litopenaeus vannami Post Larval. Iranian Scientific Fisheries Journal, 21, 39-46. http://www.isfj.ir

[22] Hussein, S.A. (1996) Electrophoretic Pattern of Serum Protein and Immunoglobulin Level in Chickens in Relation of Age. Benha Veterinary Medicine Journal, 7, 95-107. http://www.bu.edu.eg/staff/samyaziza1-publications/19249

[23] Wu, G., Yuan, C., Shen, M., Tang, J., Gong, Y., Li, D., Sun, F., Huang, C. and Han, X. (2007) Immunological and Biochemical Parameters in Carp (Cyprinus carpio) after Qompsell Feed Ingredients for Long-Term Administration. Aquaculture Research, 38, 246-255. http://dx.doi.org/10.1111/j.1365-2109.2007.01660.x

[24] Ravi, S.P. and Jitender, K.N. (2005) Fish Biology and Ecology Theory: Circulatory System of Fish. University College 
of Sciences, Osmania University, Hyderabad, 347.

[25] Kumar, G.R. and Reddy, K.P. (1999) Reduced Nociceptive Responses in Mice with Alloxan Induced Hyperglycemia after Garlic (Allium sativum Linn.) Treatment. Indian Journal of Experimental Biology, 37, 662-666. http://nopr.niscair.res.in/handle/123456789/19100

[26] Thomson, M. and Alim, M. (2003) Garlic (Allium sativum): A Review of Its Potential Use as an Anti-Cancer Agent. Current Cancer Drug Targets, 3, 67-81. http://dx.doi.org/10.2174/1568009033333736

[27] Sheela, C.G. and Augusti, K.T. (1992) Antidiabetic Effects of S-Allyl Cysteine Sulphoxide Isolated from Garlic, Allium sativum Linn. Indian Journal of Experimental Biology, 30, 523-526. http://www.ncbi.nlm.nih.gov/pubmed/1506036

[28] Adler, A.J. and Holub, B.J. (1997) Effect of Garlic and Fish-Oil Supplementation on Serum Lipid and Lipoprotein Concentrations in Hypercholesterolemic Men. The American Journal of Clinical Nutrition, 65, 445-450. http://ajcn.nutrition.org/content/65/2/445.full.pdf

[29] Warshafsky, S., Kamer, R.S. and Sivak, S. (1993) Effect of Garlic on Total Serum Cholesterol: A Meta-Analysis. Annals of Internal Medicine, 119, 599-605. http://dx.doi.org/10.7326/0003-4819-119-7_Part_1-199310010-00009

[30] Venkatramalingam, K., Godvin Christopher, J. and Citarasu, T. (2007) Zingiber officinalis an Herbal Appetizer in the Tiger Shrimp Penaeus monodon (Fabricius) Larviculture. Aquaculture Nutrition, 13, 439-443. http://dx.doi.org/10.1111/j.1365-2095.2007.00495.x

[31] Citarasu, T. (2010) Herbal Biomedicines: A New Opportunity for Aquaculture Industry. Aquaculture International, 18, 403-414. http://dx.doi.org/10.1007/s10499-009-9253-7

[32] Platel, K. and Srinivasan, K. (2004) Digestive Stimulant Action of Spices: A Myth or Reality? Indian Journal of Medical Research, 119, 167-179. http://www.ncbi.nlm.nih.gov/pubmed/15218978

[33] Mikaili, P., Maadirad, S., Moloudizargari, M., Aghajanshakeri, S. and Sarahroodi, S. (2013) Therapeutic Uses and Pharmacological Properties of Garlic, Shallot, and Their Biologically Active Compounds. Iranian Journal of Basic Medical Sciences, 16, 1031-1048. http://www.ncbi.nlm.nih.gov/pmc/articles/PMC3874089/ 
Scientific Research Publishing (SCIRP) is one of the largest Open Access journal publishers. It is currently publishing more than 200 open access, online, peer-reviewed journals covering a wide range of academic disciplines. SCIRP serves the worldwide academic communities and contributes to the progress and application of science with its publication.

Other selected journals from SCIRP are listed as below. Submit your manuscript to us via either submit@scirp.org or Online Submission Portal.
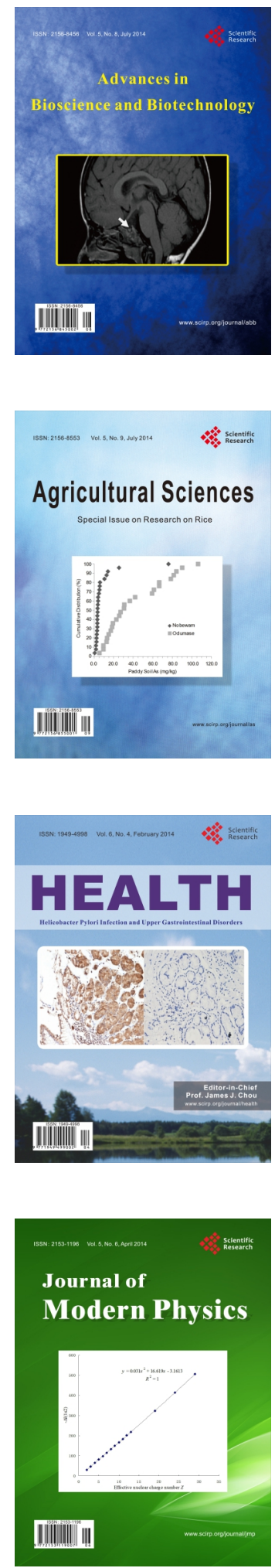
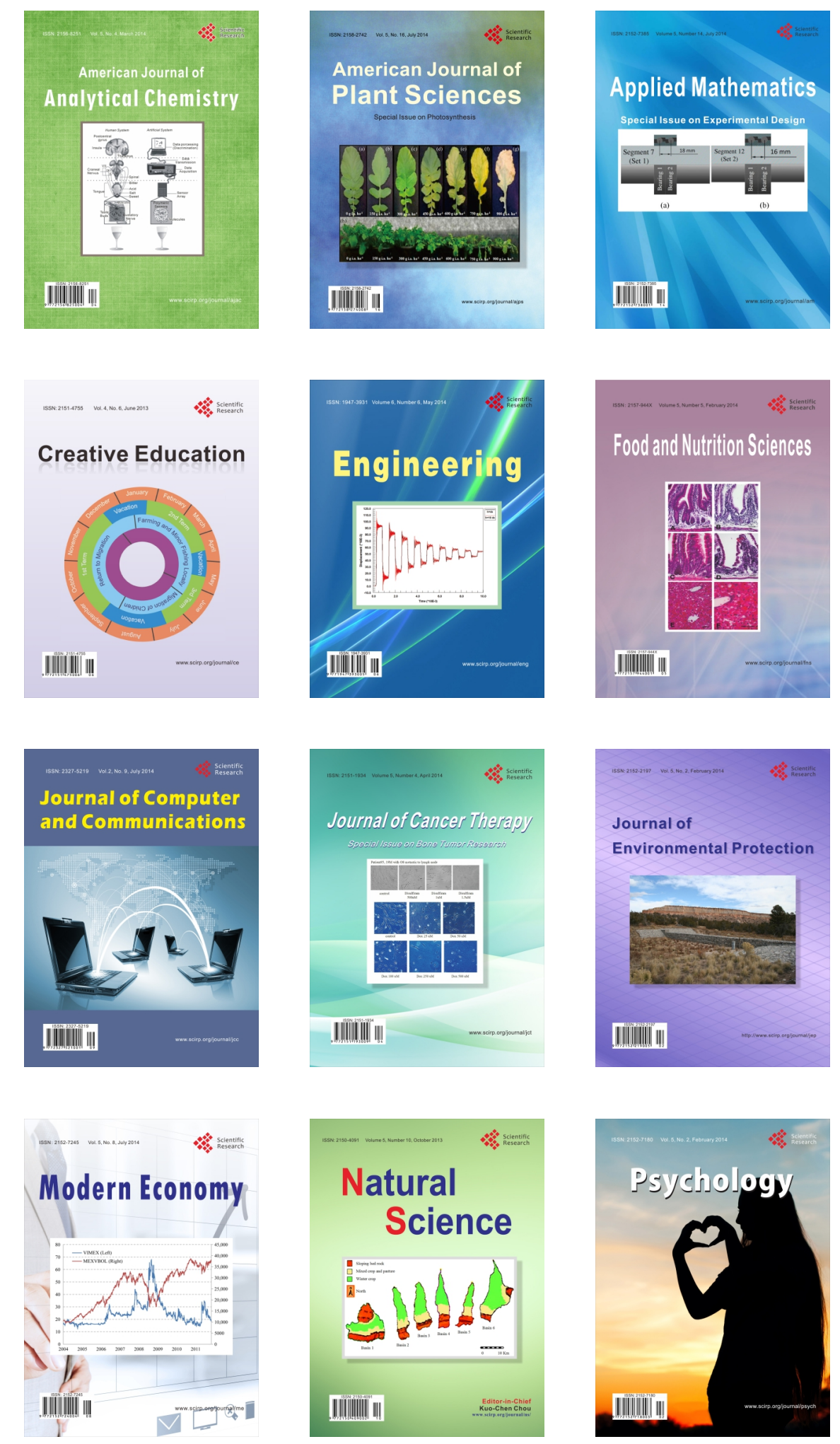